\title{
EFFECTS OF A NEW FLUORINATED MACROLIDE (P-0501A) AND OTHER ERYTHROMYCINS ON DRUG METABOLIZING ENZYMES IN RAT LIVER
}

\author{
Pia Villa*, ${ }^{\dagger}$, Fabrizio Corti, Amalia Guaitani, Ivan Bartosek, \\ Franco Casacci ${ }^{\dagger}$, Franco De Marchi ${ }^{\dagger}$ and Ernesto Pacei ${ }^{\dagger}$ \\ Istituto di Ricerche Farmacologiche "Mario Negri" \\ Via Eritrea 62, 20157 Milan, Italy \\ ${ }^{\dagger}$ R. \& D. Division, Pierrel S.p.A. \\ Via Comelico 39-41, 20135 Milan, Italy
}

(Received for publication November 7, 1985)

\begin{abstract}
The effects of a new fluorinated macrolide (P-0501A) on drug metabolizing enzymes of rat liver were compared with three erythromycins - the base, the stearate and the estolateafter 7 days of dosing $(1.36 \mathrm{mmol} / \mathrm{kg}$ po daily). The three erythromycins induced the synthesis of microsomal enzymes, but the products of their metabolism inactivated cytochrome $\mathrm{P}-450$ in the order base $\leq$ stearate $<$ estolate. $N$-Demethylation of erythromycin and aminopyrine increased, while $O$-demethylation of 4-nitroanisole was reduced and hydroxylation of aniline was not changed after in vivo treatment. Pentobarbital sleeping time was prolonged and liver glutathione levels were lower in treated rats than in controls. In contrast to the three erythromycins, P-0501A did not induce the synthesis of microsomal enzymes, did not form an inactive complex with cytochrome P-450 and did not affect mono-oxygenase activities or pentobarbital narcosis.
\end{abstract}

Erythromycin, like the other macrolide antibiotics with a tertiary amine group, induces the synthesis of drug metabolizing enzymes in rat liver. However, this induction also promotes transformation of erythromycin (demethylation and oxidation) into a metabolite which binds to the $\mathrm{Fe}$ (II) of cytochrome P-450 and inactivates $i^{1}{ }^{1}$. Several erythromycin derivatives produce similar effects and the estolate, a combination of the propionate salt of erythromycin with the detergent lauryl sulfate, appears the most active ${ }^{2,3)}$. In humans too, therapeutic doses of erythromycin propionate inactivate cytochrome P-4504). Administration of erythromycin together with ergotamine, theophylline or warfarin may provoke ischemia ${ }^{5)}$, theophylline intoxication ${ }^{6)}$ or haemorrhage ${ }^{7)}$, confirming that erythromycin interferes with drug metabolism in man. Thus, synthesis of a macrolide which does not influence detoxification of other compounds will be important for patients needing treatment with several drugs. A new fluorinated macrolide ( $(8 S)$-8-fluoroerythromycin A) (P-0501A), recently synthetized by Pierrel R. \& D. Division, Italy ${ }^{82}$ was found to have in vitro the same antibacterial activity as erythromycin base but was more stable in acid solution, more bioavailable in laboratory animals ${ }^{\theta, 10)}$ and less toxic in cell culture than the erythromycin base ${ }^{11)}$.

This paper compares the effects of P-0501A, erythromycin base, estolate and stearate on drug metabolizing enzymes in rat liver.

\section{Materials and Methods}

Chemicals

The 4 macrolides, P-0501A, erythromycin base, estolate and stearate were kindly supplied by

t† Scientist of the CNR (National Research Council) Center of cytopharmacology. 
Pierrel S.p.A., Milan, Italy. All other chemicals were analytical grade.

Animals

Male Crl: CD (SD) BR rats (Charles River, Calco, Italy) weighing 150 170 g were fed a standard diet (Altromin MT) ad lib (Rieper, Vandoies, Italy) and housed under controlled conditions (22士 $0.5^{\circ} \mathrm{C}, 55 \%$ relative humidity, $12: 12$-hour light/dark cycle).

\section{Treatments}

Rats were given orally (by gastric tube) suspensions of the erythromycins in corn oil $-1.36 \mathrm{mmol} /$ $\mathrm{kg}$ divided in two daily doses-for 7 consecutive days. Control animals received $8 \mathrm{ml}$ of corn oil $/ \mathrm{kg}$ daily. Animals were used 24 hours after the last dose for preparation of liver microsomes and for other tests.

Assays

1) Drug metabolizing enzymes-Microsomes were prepared as previously described ${ }^{12)}$ and microsomal protein ${ }^{13)}$, cytochrome $\mathrm{b}_{5}{ }^{14)}$, uncomplexed cytochrome P-450 ${ }^{14)}$ and NADPH-cytochrome c reductase ${ }^{15)}$ were determined. The total amount of cytochrome P-450 was measured by the same procedure $^{14)}$ after first adding $50 \mu \mathrm{M}$ potassium ferricyanide to another batch of microsomes. $N$ Demethylation of erythromycin ${ }^{18)}$ and aminopyrine ${ }^{17)}, O$-demethylation of 4-nitroanisol and hydroxylation of aniline ${ }^{18)}$ were assayed using both untreated and treated (50 $\mu \mathrm{M}$ ferricyanide) microsomes.

2) The in vivo formation of complexes absorbing at $456 \mathrm{~nm}$ was measured with a microsomal suspension $(2 \mathrm{mg}$ protein $/ \mathrm{ml})$ after addition of $50 \mu \mathrm{M}$ potassium ferricyanide to the reference cuvette. The difference spectrum was recorded from 400 to $500 \mathrm{~nm}^{12}$.

3) The binding spectra of erythromycins with cytochrome P-450 Fe(III) were recorded from 360 to $500 \mathrm{~nm}$ after addition of increasing amounts of the drugs dissolved in ethanol to microsomes $(2 \mathrm{mg} \operatorname{protein} / \mathrm{ml})^{1)}$.

4) Serum Enzymes: Activities of glutamate-oxalacetate transaminase (GOT) and alkaline phosphatase were measured by standard kits (Biochemia Boehringer, Mannheim, W. Germany).

5) Sleeping time induced by pentobarbital $(25 \mathrm{mg} / \mathrm{kg}$, iv) was measured by following the duration of loss of righting reflex.

6) Hepatic glutathione was evaluated as $\mathrm{SH}$ groups not bound to protein (NP-SH) ${ }^{18)}$.

7) Statistical significance of the results was analyzed by DunNETT's test ${ }^{20)}$.

\section{Results}

Seven days' treatment of rats with P-0501A, erythromycin base and stearate $(1.36 \mathrm{mmol} / \mathrm{kg}$ po daily), did not alter body weight, or activities of S-GOT and alkaline phosphatase in comparison with controls (data not shown). Only erythromycin estolate slowed the increase of body weight starting from the 4th day of treatment. The increases in liver weight, in the concentration of microsomal

Table 1. Effects of various erythromycins (E) on hepatic drug-metabolizing enzymes.

\begin{tabular}{|c|c|c|c|c|}
\hline $\begin{array}{c}\text { Treatment } \\
(1.36 \mathrm{mmol} / \mathrm{kg} \\
\text { daily) } \\
\text { for } 7 \text { days }\end{array}$ & $\frac{\text { Liver weight }}{\text { Body weight }}(\%)$ & $\begin{array}{l}\text { Microsomal } \\
\text { protein } \\
(\mathrm{mg} / \mathrm{g} \text { liver })\end{array}$ & $\begin{array}{c}\text { NADPH-cytochrome c } \\
\text { reductase } \\
\text { (nmol/minute } / \mathrm{mg} \\
\text { protein) }\end{array}$ & $\begin{array}{c}\text { Cytochrome } b_{5} \\
\text { (nmol/mg protein) }\end{array}$ \\
\hline Control & $4.5 \pm 0.1$ & $22.3 \pm 0.6$ & $97.4 \pm 3.5$ & $0.511 \pm 0.013$ \\
\hline E. Base & $5.0 \pm 0.1^{\mathrm{b}}$ & $23.0 \pm 0.6$ & $116.3 \pm 4.8^{\mathrm{a}}$ & $0.600 \pm 0.017^{\mathrm{b}}$ \\
\hline E. Stearate & $4.7 \pm 0.1$ & $22.2 \pm 0.9$ & $108.7 \pm 7.5$ & $0.569 \pm 0.014^{\mathrm{a}}$ \\
\hline E. Estolate & $5.0 \pm 0.1^{\mathrm{b}}$ & $25.8 \pm 0.8^{\mathrm{b}}$ & $150.7 \pm 4.9^{b}$ & $0.618 \pm 0.008^{b}$ \\
\hline P-0501A & $4.5 \pm 0.1$ & $21.0 \pm 0.4$ & $93.9 \pm 6.8$ & $0.519 \pm 0.017$ \\
\hline
\end{tabular}

Results are means \pm S.E.M. of nine rats.

a $P<0.05$ vs. control (DunNeTt's test).

b $P<0.01$ vs. control (DunNeTT's test). 
Table 2. Effects of various erythromycins (E) on the hepatic monoxygenase system.

\begin{tabular}{|c|c|c|c|c|c|c|}
\hline $\begin{array}{c}\text { Treatment } \\
(1.36 \mathrm{mmol} / \mathrm{kg} \\
\text { daily) } \\
\text { for } 7 \text { days }\end{array}$ & $\begin{array}{l}\text { Uncomplexed } \\
\text { cytochrome } \\
\text { P-450 } \\
\text { (nmol/mg }\end{array}$ & $\begin{array}{l}\text { Total } \\
\text { cytochrome } \\
\text { P-450 } \\
\text { protein) }\end{array}$ & $\begin{array}{c}\text { Complexed } \\
\text { cytochrome } \\
\text { P-450 } \\
(\%)\end{array}$ & $\begin{array}{c}\begin{array}{c}\text { Induced } \\
\mathrm{P}-450^{\mathrm{a}}\end{array} \\
\text { Control } \\
\mathrm{P}-450\end{array}$ & 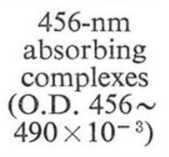 & $\begin{array}{c}\text { Reverse type I } \\
\text { binding } \\
\text { spectrum } \\
(\mathrm{O} . \mathrm{D} .390 \sim \\
\left.422 \times 10^{-3}\right)\end{array}$ \\
\hline Control & $0.67 \pm 0.05$ & $0.60 \pm 0.05$ & - & 1.00 & $\mathrm{ND}^{\mathrm{b}}$ & ND \\
\hline E. Base & $0.84 \pm 0.04^{c}$ & $1.08 \pm 0.05^{\mathrm{d}}$ & 22 & 1.80 & $26.2 \pm 2.4$ & $21.9 \pm 2.1$ \\
\hline E. Stearate & $0.93 \pm 0.06^{d}$ & $1.17 \pm 0.16^{\mathrm{d}}$ & 21 & 1.95 & $16.8 \pm 1.9$ & $18.0 \pm 2.0$ \\
\hline E. Estolate & $1.05 \pm 0.05^{\mathrm{d}}$ & $1.93 \pm 0.07^{\mathrm{d}}$ & 46 & 3.22 & $130.0 \pm 4.9$ & $200.0 \pm 8.2$ \\
\hline P-0501A & $0.66 \pm 0.03$ & $0.61 \pm 0.05$ & - & 1.00 & ND & ND \\
\hline
\end{tabular}

Results are means \pm S.E.M. of nine rats.

a Ratio of cytochrome P-450 in treated and control rats.

b ND: Not detectable.

c $P<0.05$ vs. control (DunNeTT's test).

d $P<0.01$ vs. control (DunNeTt's test).

protein, NADPH-cytochrome $c$ reductase and cytochrome $b_{5}$ showed that erythromycin base, stearate and particularly estolate were inducers of hepatic drug metabolizing enzymes (Table 1). The concentration of CO-binding, free cytochrome P-450 was also significantly raised in livers of treated rats. However, part of the cytochrome P-450 was bound in complexes with erythromycin metabolites and did not bind CO (Table 2). The Soret peak determined in the cytochrome complexes at $456 \mathrm{~nm}$ was similar in rats treated with erythromycin base and stearate, but much higher in animals treated with estolate. The reverse type I binding spectrum of erythromycins to microsomes was also similar for the base and stearate and bigger for the estolate (Table 2). Correspondingly, $N$-demethylation of erythromycin and aminopyrine increased, particularly after breaking the complex with potassium ferricyanide (Table 3). Other enzymatic activities were affected to different degrees by erythromycin treatment; $O$-demethylation of 4-nitroanisole was significantly reduced by estolate (Table 3 ) and was not influenced by the treatment with ferrycyanide, hydroxylation of aniline was not changed (data not shown). Pentobarbital sleeping time increased after erythromycin base, stearate and estolate (Table 3). Levels of hepatic glutathione were reduced after treatment with estolate and base (Table 4).

In contrast, P-0501A did not induce biosynthesis of microsomal enzymes; liver weight, microsomal protein concentration, cytochrome $b_{5}$ content and NADPH-cytochrome $c$ reductase were not changed (Table 1). The concentration of cytochrome P-450 was not modified, and there was no evidence of complex formation between metabolites of P-0501A and cytochrome P-450. The microsomes did not give any Soret peak at $456 \mathrm{~nm}$ and their CO-binding capacity was not influenced by the addition of potassium ferricyanide (no binding spectrum was induced by pretreatment with the fluorinated macrolide (Table 2)). P-0501A demethylation in non-treated controls was significantly higher than that of the other three erythromycins but in P-0501A-treated rats its demethylation was increased by only $30 \%$ (Table 3 ). $\mathrm{N}$-Demethylation of aminopyrine, $\mathrm{O}$-demethylation of 4-nitroanisole and hydroxylation of aniline were not significantly modified. Pentobarbital sleeping time was similar to controls (Table 3) and levels of hepatic glutathione were not reduced by the treatment (Table 4).

\section{Discussion}

Repeated administration of erythromycins to humans and rats induces biosynthesis of microsomal enzymes and promotes formation of metabolites which bind and inactivate cytochrome P-450. The 
Table 3. Effects of various erythromycins (E) on hepatic microsomial activities.

\begin{tabular}{|c|c|c|c|c|c|c|c|c|}
\hline \multirow{2}{*}{\multicolumn{2}{|c|}{$\begin{array}{l}\text { Treatment } \\
(1.36 \mathrm{mmol} / \mathrm{kg} \text { daily) } \\
\text { for } 7 \text { days }\end{array}$}} & \multirow{2}{*}{\multicolumn{2}{|c|}{$\begin{array}{c}\begin{array}{c}\text { Erythromycin demethylase* } \\
\text { (nmol HCHO/10 minutes/mg protein) }\end{array} \\
\text { Potassium ferricyanide }(\%)^{\mathrm{a}}\end{array}$}} & \multirow{2}{*}{\multicolumn{2}{|c|}{$\begin{array}{c}\begin{array}{c}\text { Aminopyrine } N \text {-demethylase } \\
\text { (nmol product } / 30 \text { minutes } / \text { mg protein) }\end{array} \\
\text { Potassium ferricyanide }(\%)\end{array}$}} & \multirow{3}{*}{$\begin{array}{c}\begin{array}{c}4-\mathrm{NO}_{2} \text { Anisole } \\
\text {-demethylase** } \\
\text { (nmol product/ }\end{array} \\
\begin{array}{c}30 \text { minutes/mg } \\
\text { protein) }(\%)\end{array} \\
9.4 \pm 0.5\end{array}$} & \multicolumn{2}{|c|}{$\begin{array}{l}\text { Pentobarbital } \\
\text { sleeping time }\end{array}$} \\
\hline & & & & & & & \multirow{2}{*}{$\begin{array}{c}\text { minutes } \\
21 \pm 1\end{array}$} & \multirow{2}{*}{$\begin{array}{l}\% \\
(100)\end{array}$} \\
\hline \multirow{5}{*}{\multicolumn{2}{|c|}{$\begin{array}{l}\text { Control Substrate } \\
\text { E. Base } \\
\text { E. Stearate } \\
\text { E. Estolate } \\
\text { P-0501A }\end{array}$}} & & & $7.2 \pm 0.6$ & $8.2 \pm 0.6(100)$ & & & \\
\hline & & $5.6 \pm 0.9$ & $5.8 \pm 0.8(100)$ & & & & & \\
\hline & & $5.3 \pm 1.0$ & $5.2 \pm 1.1(100)$ & & & & & \\
\hline & & $6.1 \pm 0.8$ & $6.2 \pm 0.5(100)$ & & & & & \\
\hline & & $10.5 \pm 1.2^{\mathrm{e}}$ & $10.6 \pm 1.6^{\mathrm{c}}(100)$ & & & & & \\
\hline \multicolumn{2}{|c|}{ E. Base } & $16.8 \pm 1.4^{\mathrm{d}}$ & $20.5 \pm 1.5^{\mathrm{d}}(354)$ & $7.5 \pm 0.3$ & $10.5 \pm 0.4^{e}(128)$ & $8.1 \pm 0.5(87)$ & $38 \pm 6^{\mathrm{d}}$ & (181) \\
\hline \multicolumn{2}{|c|}{ E. Stearate } & $14.6 \pm 1.6^{\mathrm{d}}$ & $18.5 \pm 2.7^{\mathrm{d}}(356)$ & $8.7 \pm 0.8$ & $11.1 \pm 0.7^{e}(136)$ & $8.1 \pm 0.9(87)$ & $41 \pm 4^{\mathrm{d}}$ & (195) \\
\hline \multicolumn{2}{|c|}{ E. Estolate } & $22.8 \pm 2.4^{\mathrm{d}}$ & $27.8 \pm 2.6^{\mathrm{d}}(444)$ & $9.5 \pm 0.6^{\mathrm{e}}$ & $13.8 \pm 0.9^{\mathrm{d}}(169)$ & $6.2 \pm 0.3^{d}(66)$ & $44 \pm 3^{d}$ & (210) \\
\hline \multicolumn{2}{|c|}{ P-0501A } & $14.1 \pm 0.7^{\mathrm{e}}$ & $14.0 \pm 1.0^{\circ}(131)$ & $8.5 \pm 1.0$ & $9.8 \pm 1.0(120)$ & $9.7 \pm 0.4(103)$ & $26 \pm 3$ & (124) \\
\hline
\end{tabular}

Results are means \pm S.E.M. of seven rats.

* Demethylation of E. Base, E. Stearate, E. Estolate and P-0501A was studied in rats treated with the corresponding erythromycins.

** There was no difference between results obtained with ferricyanide treated and untreated microsomes (see text).

a Activity is expressed as a percentage of the corresponding control.

b Pentobarbital was given intravenously at the dose of $25 \mathrm{mg} / \mathrm{kg}$.

c $P<0.01$ vs. E. Base, E. Stearate and E. Estolate (DunNeTT's test).

d $P<0.01$ vs. control (DUNnETT's test).

- $P<0.05$ vs. control (DunNeTT's test). 
hydrophobic character of the erythromycin molecule and the presence of an accessible $N$ dimethylamino group seem responsible for this ${ }^{3)}$. In fact, erythromycin estolate, being more hydrophobic than the base and stearate, is more active in inducing enzymes of the microsomal mixed function oxidase system, cytochrome $b_{5}$, NADPH-cytochrome c reductase and cytochrome P-450. Moreover, the amount of cytochrome P-450 inactivated by complexing with erythromycin estolate is double that formed with the base and stearate. Our data are in agreement with previous results ${ }^{3)}$.

Erythromycins induce more $N$-demethylation of various substrates (aminopyrine, erythromycin) than $O$-demethylation or hydroxylation and reduce the concentration of glutathione in liver ( $c f$. troleandomycin ${ }^{21)}$ ).

The characteristics of the new fluorinated macrolide P-0501A differ from those of the other erythromycins studied. P-0501A is more stable in acid solution, suggesting less inactivation in the stomach $^{9)}$, reaches higher blood levels in laboratory animals ${ }^{9,10)}$ and is less toxic for cultured liver cells $^{11)}$. P-0501A does not induce biosynthesis of microsomal enzymes and does not form cytochrome P-450 metabolite complexes. In untreated controls it is demethylated more than the other erythromycins, though, after prolonged treatment, its metabolism increases only slightly (by 30\%). However, the demethylation observed may be that of the methoxy function, rather than that of the tertiary amine function, of the fluorinated macrolide.

It may be interesting to study the formation of P-0501A metabolites in order to understand the drug's different effect on monooxygenase activities. It has been shown ${ }^{22,23)}$ that the replacement of an atom of hydrogen by fluorine, which is nearly isosteric but considerably more electro-negative than hydrogen, may significantly affect the chemical and biological properties of the molecule or of the neighboring groups. Actually the partition coefficient of P-0501A is considerably lower than that of erythromycin base (data not shown). This characteristic may explain why the molecule does not affect the mono-oxygenase system and agrees with data referring to other erythromycins ${ }^{2,3)}$. All these properties of P-0501A suggest that this new antibiotic may offer some advantages for therapeutic purposes.

\section{References}

1) Danan, G.; V. Descatorre \& D. Pessayre: Self-induction by erythromycin of its own transformation into a metabolite forming an inactive complex with reduced cytochrome P-450. J. Pharmacol. Exp. Ther. 218: 509 514, 1981

2) Larrey, D.; M. Tinel \& D. Pessayre: Formation of inactive cytochrome P-450 FelI-metabolite complexes with several erythromycin derivatives but not with josamycin and midecamycin in rats. Biochem. Pharmacol. 32: 1487 1493, 1983

3) Delaforge, M.; M. Jaouen \& D. Mansuy: Dual effects of macrolide antibiotics on rat liver cytochrome P-450. Biochem. Pharmacol. 32: 2309 2318, 1983

4) Larrey, D.; C. Funck-Brentano, P. Breil, J. Vitaux, C. Theodore, G. Babany \& D. Pessayre: Effects of erythromycin on hepatic drug metabolizing enzymes in humans. Biochem. Pharmacol. 32: 1063 1068,1983

5) Fiessingerm, J. N. \& J. Rauffett: Complications vasculaires de certaines medications. J. Maladies Vasculaires 3: $261 \sim 263,1978$

6) May, D. C.; C. H. Jarboe, D. T. Ellenburg, E. J. Roe \& J. Karibo: The effects of erythromycin on theophylline elimination in normal males. J. Clin. Pharmacol. 22: 125 130, 1982

7) Bartle, W. R.: Possible warfarin-erythromycin interaction. Arch. Int. Med. 140: 985 987, 1980

8) Toscano, L.: G. Fioriello, R. Spagnoli, L. Cappelletti \& G. Zanuso: New fluorinated erythromycins obtained by mutasynthesis. J. Antibiotics 36: 1439 1450, 1983 
9) Zanuso, G.; L. Toscano, R. Pezzali \& E. Seghetti: Novel macrolide antibiotic with high acid stability: Synthesis and biological activity. Abstracts of Papers of 13th International Congress of Chemotherapy. Part 107, No. 12, Vienna, 1983

10) Zanuso, G. \& R. Pezzali: Macroflumycin, a new fluorinated macrolide antibiotic: In vitro and in vivo studies. Abstracts of Papers of 6th International Symposium on Future Trends in Chemotherapy, p. 221, Tirrenia, Italy, 1984

11) Villa, P.; J.-M. Begue \& A. Guillouzo: Effects of erythromycin derivatives on cultured rat hepatocytes. Biochem. Pharmacol. 33: 4098 4101, 1984

12) Cinti, D. L.; P. Moldeus \& J. B. Schenkman: Kinetic parameters of drug-metabolizing enzymes in $\mathrm{Ca}^{2+}$-sedimented microsomes from rat liver. Biochem. Pharmacol. 21: 3249 3256, 1972

13) Lowry, O. H.; N. J. Rosebrough, A. L. Farr \& R. J. Randall: Protein measurement with the folin phenol reagent. J. Biol. Chem. 193: 265 275, 1951

14) Omura, T. \& R. Sato: The carbon monoxide-binding pigment of liver microsomes. I. Evidence for its hemoprotein nature. J. Biol. Chem. 239: 2370 2378, 1964

15) Dallner, G.; P. Siekewitz \& G. E. Pallade: Biogenesis of endoplasmic reticulum membranes. II. Synthesis of constitutive microsomal enzymes in developing rat hepatocyte. J. Cell. Biol. 30: 97 117, 1966

16) MaO, J. C.-H. \& P. L. TARDrew: Demethylation of erythromycins by rabbit tissues in vitro. Biochem. Pharmacol. 14: 1049 1058, 1965

17) La Du, B. N.; L. Gaudette, N. Trousof \& B. B. Brodie: Enzymatic dealkylation of aminopyrine and other alkylamines. J. Biol. Chem. 214: 741 752, 1955

18) Gilbert, D. \& L. Golberg: Liver response tests. 3. Liver enlargement and stimulation of microsomal processing enzyme activity. Fd. Cosmet. Toxicol. 3: 417 432, 1965

19) Sedlak, J. \& R. H. Lindsay: Estimation of total, protein-bound, and nonprotein sulfhydryl groups in tissue with Ellman's reagent. Anal. Biochem. 25: 192 205, 1968

20) Dunnett, C. W.: A multiple comparison procedure for comparing several treatments with control. J. Am. Stat. Assoc. 50: 1096 1121, 1965

21) Pessayre, D.; M. Tinel, D. Larrey, B. Cobert, C. Funck-Brentano \& G. Babany: Inactivation of cytochrome P-450 by a troleandomycin metabolite. Protective role of glutathione. J. Pharmacol. Exp. Ther. 224: 685 691, 1983

22) Stern, A. M.; B. M. Foxman, A. H. Tashjian, Jr. \& R. H. Abeles: Dl-threo- $\beta$-Fluoroaspartate and DL-threo- $\beta$-fluoroasparagine: Selective cytotoxic agents for mammalian cells in culture. J. Med. Chem. 25: $544 \sim 550,1982$

23) Goldman, P.: The carbon-fluorine bond in compounds of biological interest. Science 164: 1123 1130, 1969 